\title{
GROUP-BASED DIRECT AND INDIRECT APPROACHES TO LANGUAGE THERAPY FOR CHILDREN WITH DEVELOPMENTAL LANGUAGE DISORDER: A PRE-EXPERIMENTAL STUDY
}

\author{
Ana Matić \\ Department of Speech and Language Pathology, University of Zagreb \\ Borongajska street 83 f, 10000 Zagreb \\ ana.matic@erf.hr \\ Jelena Kuvač Kraljević \\ Department of Speech and Language Pathology, University of Zagreb \\ Borongajska street $83 \mathrm{f}, 10000$ Zagreb \\ jelena.kuvac@erf.hr \\ Lana Kologranić Belić \\ Polyclinic for the Rehabilitation of Listening and Speech SUVAG \\ Mokrička street 54, 10290 Zaprešić \\ lana.kologranic@gmail.com \\ Marina Olujić Tomazin \\ Department of Speech and Language Pathology, University of Zagreb \\ Borongajska street $83 \mathrm{f}, 10000$ Zagreb \\ marina.olujic@erf.hr
}

\begin{abstract}
Developmental Language Disorder (DLD) is among the most frequent communication disorders in early childhood. It affects the quality of the child's academic and social life. Speech-language therapy to counter this impairment is usually individual and based on a direct approach with the therapist. New approaches begin to emerge, involving group settings, as well as indirect involvement of a parent who is constantly monitored and supervised by the therapist. Group and indirect therapies are infrequently used in Croatia, even though their effectiveness is well demonstrated worldwide.

The aims of the current study were: 1) to examine whether two approaches to language therapy: group-based direct and indirect at home, can foster early literacy in children with DLD, and 2) to gain insight into parental perception of group therapy and how they perceived its potential influence on their children's lives. It has a pre-experimental design and thus presents the first step towards an evidence-based effectiveness study. Eight children and their parents participated in the programme. Children's language progress was measured using language tests before and after the
\end{abstract}


programme, and parents' perception of the therapy was evaluated using a post-programme questionnaire.

The results suggest that group-based direct and indirect approaches can foster early literacy in preschool children with DLD. Parental perception of the therapy was positive; they expressed strong trust in the therapy and reported finding it useful for their children. The outcomes of the present pre-experimental study further corroborate positive effects of carefully planned therapies and serve as a step forward in conducting effectiveness studies in order to establish evidence-based practices in Croatia.

Keywords: developmental language disorder, pre-experimental study, group language therapy, direct and indirect approaches, early literacy

\section{INTRODUCTION}

Nearly 6 million children and young people in Europe have language impairments (European Commission/EACEA/Eurydice/Eurostat, 2014) that affect their educational progress, mental health, employment prospects, socialisation, behaviour and overall quality of life (Botting \& Conti-Ramsden, 2000; Law, Rush, Parsons \& Schoon, 2009). Such impairments are the most frequent learning-related disabilities noted among preschool and school-age children (Wake et al., 2012), who are typically referred to a speech and language pathologist (SLP) for therapy (Roulstone, Wren, Bakopoulou, Goodlad \& Lindsay, 2012).

Several modes of language therapy exist and can be based on interaction between an SLP and either an individual or a group of individuals with the same diagnosis of an impairment. Therapies can also be direct, meaning that the SLP bears full responsibility for delivering the training; or indirect, meaning that a parent, supervised by an SLP, in some aspects helps deliver the training (Boyle, 2007).

Even though group therapies are recognised as highly effective and have been implemented in certain parts of the world, i.e. UK or North America (Boyle, 2007; Law, Garrett \& Nye, 2003; Law, Garrett \& Nye, 2010; Law, Garrett, Nye \& Dennis, 2012a), their appropriateness is still debated and therefore they remain relatively uncommon in most European countries, including Croatia. Thus, most SLPs across Europe work with one child and rarely involve other persons closely related to the child, such as parents. A comprehensive discussion on identifying the most effective service provision to children with Developmental Language Disorder (DLD) has taken on a new urgency across Europe. Croatia aspires to reach the same goals, hence the motivation to start gathering empirical evidence and conducting a preexperimental effectiveness study.

Effectiveness of a group-based approach to language therapy

Regardless of the approach to language therapy, the SLP primarily bears the responsibility for its planning, directing and evaluating, and this requires appro- 
priate interaction of knowledge, approach and skills (Bray, Todd \& Ross, 2005). The burgeoning number of published programmes of different therapies around the world led UK researchers to classify them and analyse their effectiveness (Lindsay, Dockrell, Law \& Roulstone, 2012). They identified 57 effective therapeutic interventions, $39 \%$ of which focus on language, $30 \%$ on speech and the remainder on speech, language and communication disorders (Law et al., 2012b). Moreover, there is an emerging number of systematic reviews of randomised controlled trials and meta-analyses of language therapies (Cirrin \& Gillam, 2008; Law et al., 2003, 2010, 2012a; Schooling, Venediktov \& Leech, 2010) which mostly focus on categorising, analysing and reporting their effectiveness by comparing them from different aspects, such as: 1) the main focus of the therapy (phonology, vocabulary, syntax); 2) responsiveness or reluctance to progress considering the type of language impairment (expressive vs. receptive); 3 ) approach to the therapy (individual vs. group and direct vs. indirect) and its impact on efficiency and the desired outcomes; and 4) dosage.

The systematic review by Cirrin and Gillam (2008) reports moderate-to-high effect sizes for effectiveness of different approaches to language intervention (e.g., classroom-based, individual, group) for school-age children with language disorders. Law et al.'s (2003) meta-analysis suggests that well-structured speech and language therapy is effective for children with phonological or vocabulary difficulties; however, there is less evidence for intervention effectiveness for children with receptive difficulties. Liberman and Michael (1986) emphasise that while individual therapy serves as a direct support for establishing and stabilising specific speech and language behaviours, group therapy is additionally directed towards the development of appropriate interpersonal and social skills. Since group therapy is based on cooperative learning, prior to its start an SLP has to specify a) the language objectives, i.e. language targets that are specific to each group member, and $b$ ) the cooperative objectives, i.e. rules of language use in social context. Group therapy can elicit a high level of parental trust and confidence in the therapy, especially when combined with an indirect component (Johnson, Moffatt, Smith \& White, 2012).

\section{Benefits of an indirect approach to language therapy}

Multiple benefits of indirect language therapy have been emphasised. Children's gains can be multiplied when the therapy is provided directly by an SLP and indirectly by a parent, who is constantly supervised by the SLP. McCartney, Boyle, Ellis, Bannatyne and Turnbull (2011) accentuate that monitoring is of crucial importance, and that indirect therapy providers need to be well instructed and guided by an expert. Parental involvement might be of crucial importance, not only for improving the outcomes, but also for developing the trusting relationship between therapists, parents and children. It has been reported that parents are those who usu- 
ally recognise speech and language delays in their children first and, if not included in the therapy process from the beginning, might develop negative attitudes towards therapy providers (Rannard, Lyons \& Glenn, 2005). Roulstone and Lindsay (2012) conducted a major study on the overall attitudes regarding therapy provision from the perspective of both children with impairments and their parents. When asked about their awareness of the difficulties, attitudes about the overall quality of life and their fears regarding the future, children have mostly reported significant concerns related to insufficient social inclusion in the community. Parental perspective was observed on a deeper level. Their views on the needs of children, their satisfaction with the therapy children were involved in, and expectations about its outcomes were discussed. Parents seem to feel they are inadequately acquainted with the diagnostic categories and the terms used by the experts, and insufficiently included in the entire process and course of the therapy. In respect of questions relating to the outcomes, they find it essential for their child to become independent and equally included in the community, and to gain more self-esteem.

It can be concluded that therapists have to work for the benefit of the child, but the goals of the therapy must be presented to the parents, who should be allowed to have access to all the desired information throughout the therapy. This may be one of the steps in enhancing their emotional competence and reducing emotional and behavioural problems in language-impaired children (Gregl, Kirigin, Sućeska Ligutić \& Bilać, 2014). Johnson et al. (2012) reported that the parents who have been involved in the therapy from the very beginning expressed strong trust and satisfaction. Namely, the results of the questionnaire developed by the therapy providers have shown that $80-100 \%$ of parents were satisfied with the amount of participation, opportunities they have been given to acquire skills that can further help their children, as well as with their children's overall progress. The results also showed that the parents had a high level of trust in the therapy and the SLPs who provided it (Johnson et al., 2012).

\section{The present study}

During the last 20 years, the tendency of conducting more evidence-based practices increases throughout Europe in all clinical fields, including SLP. In line with these tendencies, the current study presents a pre-experimental stage of the subsequent comprehensive evidence-based effectiveness study in the Croatian language.

The conducted programme aimed at fostering early literacy abilities in children with DLD, with phonic approach being the focus of the intervention. The underlying rationale behind the phonic approach is the fact that early literacy (phonological awareness, letter knowledge, vocabulary, narrative ability, interest in print and concepts of print (Daly, Chafouleas \& Skinner, 2005) forms the foundation of fluent reading and writing later on and has a strong effect on future education and life qu- 
ality. Additionally, according to Lonigan and Shanahan (2011), children with DLD particularly benefit from the phonic approach to therapy (establishing the grapheme-phoneme connection and letter knowledge).

The current study thus had two aims: 1) to examine whether group-based direct and indirect approaches to therapy can foster early literacy in preschool children with DLD and 2) to gain insights into parental perception of the group therapy, and to investigate how they felt it influenced their children's lives. It is expected that children with DLD will make progress in early literacy abilities after the groupbased language therapy and that the parents will find it useful for their children, as they will report positive gains.

\section{METHODS}

\section{Participants}

Children. Eight preschool children with DLD participated in the study (6 M and $2 \mathrm{~F}$ ) aged 5;8-6;9 (median $(\mathrm{Mdn})=6 ; 1$; interquartile range $(\mathrm{Q})=0.48)$. Children were recruited from among 15 children who had been referred to SLP services for assessment procedures one month before the start of the study. They have not been previously included in any medical treatments nor SLP services, but were recognised by their parents or kindergarten teachers as language-delayed. Inclusion criteria were the presence of language impairment in the absence of cognitive deficit, hearing loss and other developmental delays. A psychologist and an SLP assessed each child's eligibility for the study using the standardised and non-standardised tests for nonverbal IQ and language performance. Nonverbal IQ was measured using the Raven's Coloured Progressive Matrices ${ }^{\mathrm{TM}}\left(\mathrm{CPM}^{\mathrm{TM}}\right)$ (Raven, 1995). None of the 15 referred children had a nonverbal IQ below average. Language assessment was conducted using the Croatian version of the Test for Reception of Grammar (TROG2:HR); (Bishop, Kuvač Kraljević, Hržica, Kovačević \& Kologranić Belić, 2014). Eight children showed TROG-2:HR scores at least 1 SD below the mean (scores ranged from 76 to 82) and performed below expectations on the non-standardised materials. These eight children were included in the programme and further divided into two groups of four, based on the recommended maximum group size (American Speech-Language-Hearing Association - ASHA, 2011). The variances of the two groups were homogeneous in terms of age (Levene Statistics (LS) $=0.949, \mathrm{p}$ $>0.05)$, nonverbal IQ scores ( $\mathrm{LS}=1.030, \mathrm{p}>0.05)$ and performance on language tests - TROG-2:HR (LS $=0.000, p>0.05)$ and Test for the assessment of reading and writing prerequisites (PredČiP) $(\mathrm{LS}=0.040, \mathrm{p}>0.05)$.

Parents. Eight parents were enrolled in the study (7 F and $1 \mathrm{M})$, corresponding to one parent per child in the programme. The majority of parents had University degrees (5), two had upper secondary education and one parent had basic education. 


\section{Instruments}

Therapy outcomes were evaluated by administering two tests standardised on the Croatian language: (1) the TROG-2:HR and (2) the PredČiP (Kuvač Kraljević \& Lenček, 2012), one month before the programme and one month after the last session. The tests were applied directly to the children by an SLP not included in the therapy nor familiarised with the study aims. The significant progress at the second time point would suggest a significant effect of the therapy.

The TROG-2:HR is used for assessing comprehension of Croatian grammar with respect to flexion, functional words and word order. It consists of 80 items, i.e. sentences of varying complexity that are ordered from lower to higher complexity. The child has to select one of the four images that correspond to the sentence presented to him/her orally. It is used as a measure of language performance and, due to its high reliability ( $\alpha=0.956$ ), it is considered a valuable indicator of language difficulties, be it purely syntactic or more general. This is the reason why it was used both as an inclusion criterion (in a pre-test) and in a post-test phase, 9 months after the programme (which is the minimum time before the re-test, as suggested in the test manual).

The PredČiP test aligns closely with the phonic approach, since it primarily assesses meta-phonological abilities, i.e., early prerequisites of reading and writing or literacy (Daly et al., 2005). The instrument uses four types of assignments, but since the phonic approach relies mostly on letter knowledge and phonological awareness, these two abilities were considered the most important for the current study.

Phonology consists of:

a) Rapid automated naming task $(\alpha=0.979)$ - the ability to access phonological codes quickly by naming 20 pictures.

b) Phonological awareness tasks $(\alpha=0.928)$ - Rhyming tasks ( 7 items of rhyme recognition and 7 of rhyme production), Syllable awareness tasks ( 7 items of syllable blending and 7 of syllable segmentation) and Phonemic awareness tasks ( 7 items of phonemic blending and 7 of phonemic segmentation).

c) Letter knowledge tasks - 30 items of uppercase and 30 of lowercase letter naming.

Working memory is measured using two tasks $(\alpha=0.759)$ :

a) Repetition of pseudowords (7 items)

b) Sentence repetition ( 7 items)

Visual perception is measured using two tasks:

a) Visual recognition (10 items) - the child recognises the same token in a line of five similar ones $(\alpha=0.512)$.

b) Copying of tokens (4 items) - the child redraws a specific token in the specified area $(\alpha=0.690)$. 
Narrative ability task is a task where the child has to create and tell a story based on four pictures presented to him or her, and it was assessed on one measure:

a) Syntactic complexity - the child receives one point for every complex sentence he or she produces.

In order to address the second goal of the study, i.e. to assess the parents' perception of the programme and to gain some insights into their perspective, the parents filled out a questionnaire one week after the programme. The questionnaire was based on that of Johnson et al. (2012) and consisted of 10 questions with responses on a 6-point scale, as well as four open-ended questions. Questions covered three areas and were qualitatively analysed according to them: (1) understanding of programme aims and level of trust that the programme aligned with the aims (q. 1, 2, $4,6),(2)$ satisfaction with their involvement and perceived usefulness of the five parent sessions (q. 3, 5, 7, 9) and (3) opinion about group vs. individual therapy (q. 10). Questions on a 6-point scale were answered by indicating a score of 0 to 5, with 0 meaning I cannot estimate, 1 meaning I completely disagree and 5 meaning I completely agree. The four open-ended questions asked parents to indicate (1) advantages and disadvantages of the therapy, (2) area in which their child made the greatest progress, (3) what they disliked about activities and (4) what would potentially improve future programmes.

\section{Procedures}

Before the start of research activities, the Institutional Informed Consent Form was obtained from all participants.

Group-based direct approach to language therapy. Two groups per four children $(\mathrm{N}=8)$ were given identical direct speech and language therapy administered by two SLPs, who planned the activities and prepared the materials. Activities were based on the latest empirical findings about the complexity and order of emergence of early literacy abilities in children growing up in the Croatian language (Kuvač Kraljević, Lenček \& Matešić, 2019). Activities and materials were age-appropriate in order to stimulate children's interest and maintain their attention and motivation (Johnson et al., 2012). The programme lasted six months, with each group attending 30 therapy sessions of 45 minutes each. None of the children withdrew from the programme.

Activities were in line with the phonic approach, and thus covered four major areas: (1) letter knowledge and phonological awareness, (2) print awareness and concept of print, (3) narrative abilities and (4) vocabulary. These four categories were also divided in three time periods in which they were conducted, based on their complexity and order of emergence: (1) the first several sessions dealt with letter knowledge, rhyme recognition and production and syllable awareness; (2) the next several sessions dealt again with phonological awareness, print awareness and 
concept of print; and (3) the last several sessions dealt with phonemic awareness and narrative abilities. Vocabulary was fostered throughout these activities.

Indirect approach to language therapy: parental involvement. Parents were trained in how to help foster the target abilities in the home environment. They were present at direct group therapy sessions which they observed through a oneway mirror. They also received five 30-min group training sessions parallel to their children's therapy. This took place in a separate room and was led by the second SLP. As all activities were explained to the parents, they could use what they learned from the SLP outside the sessions. During the sessions, parents were taught about the importance of early literacy abilities and given a list of activities to implement in everyday life. The training topics covered the following areas: (1) letter knowledge, (2) rhyme, (3) print awareness and concepts of print, (4) syllable awareness and (5) phonemic awareness. Some examples of suggested activities were recognising letters while reading a storybook, cutting letters and words from newspapers, reading songs and stories that rhyme etc. Each training session started with a discussion on the implemented activities and parents had to present what they did in the home environment. For a detailed description of the parents' activities, see Matić, Kologranić Belić and Kuvač Kraljević (2015).

Children's progress was measured using pre- and post-language assessments, while the parents' satisfaction with the therapy was measured using a post-programme questionnaire.

\section{Research design and statistical analyses}

This study relied on the single group pre-experimental research design, also known as the one-group pre-and post-test design; before and after; or one-shot case design [see more in Campbell \& Stanley (1963); Marsden \& Torgerson, (2012); Tate, Perdices, McDonald, Togher \& Rosenkoetter, (2014)]. Prior to the programme, children were pre-tested in order to establish their baseline, then they were exposed to the phonic intervention programme and, finally, post-tested. The rationale for conducting a pre-experimental study was to gain preliminary data for forthcoming evidence-based effectiveness studies in the Croatian language. The importance of gaining empirical evidence and conducting evidence-based practice has been recognised within speech and language pathologists' communities worldwide, but no such tendencies existed in Croatia until recently.

Data from the two groups were pooled because they were similar in terms of gender composition, age, nonverbal IQ, TROG-2:HR score and performance on PredČiP subtests (see section Participants). Responses on the two language tests (TROG-2:HR and PredČiP) were compared before and after the programme using the non-parametric, repeated-measures Wilcoxon signed test because the sample size was small and the data were not normally distributed. Data were reported as 
medians (Mdn) and interquartile ranges (Q). To compensate for the lack of a control group and in order to control for any maturation effect, standardised growth expectation (SGE) has been calculated. It is a statistical method which uses difference between the pre- and post-test z-scores as the amount of loss in relative standing that a participant would suffer if he/she had no benefit from the therapy administered. SGE was first defined by Stenner, Hunter, Bland and Cooper (1978) as: "the amount of growth (expressed in standard deviation form) that a student must demonstrate over a given treatment interval to maintain his/her relative standing in the norm group". It is calculated in the following way: (1) the scale score associated with $50^{\text {th }}$ percentile for the pre-test is identified, (2) the percentile rank for the post-test associated with this scale score is found, (3) percentiles are converted to $\mathrm{z}$-scores and (4) z-score for the post-test is subtracted from the z-score for the pretest. This difference between pre- and post-test z-scores is the SGE. This procedure allows assessing whether the children's standing relative to the normative group changes from pre- to post-test, and thus, how the gains observed compare to the gains expected due to maturation alone. When comparing change across different time periods, this methodology assumes that the test administered each time provides a measure of the same construct based on identical content (Russell, 2000).

Parents' responses to the ten 6-point questions on the post-programme questionnaire were analysed using descriptive statistics, while their responses to the four open-ended questions were analysed qualitatively.

\section{RESULTS}

Group-based direct and indirect approaches to language therapy: progress on early literacy measures

Comparison of test results before and after the programme showed that children performed better after the programme. This was visible in statistical pre- vs. postprogramme comparisons using the Wilcoxon signed test, which showed large effect sizes (Table 1).

These results indicate that children made progress in most of the targeted early literacy abilities. The greatest advances were related to Letter knowledge, Rhyme, Phonemic awareness and Syntactic complexity of storytelling. At baseline, TROG2:HR scores, which are expressed on a standardised scale, were below average for the children's age ( $\mathrm{Mdn}=79.00 ; \mathrm{z}=-1.4 \sigma)$; after the programme, the scores were average for the age $(\mathrm{Mdn}=88.5 ; \mathrm{z}=-0.77 \sigma)$, with four of eight children achieving above-average scores.

In order to control the influence of language therapy on the progress achieved and to claim with more reliability that the changes cannot be attributed to other variables, SGE method was used on the results of the standardised TROG-2:HR test. 


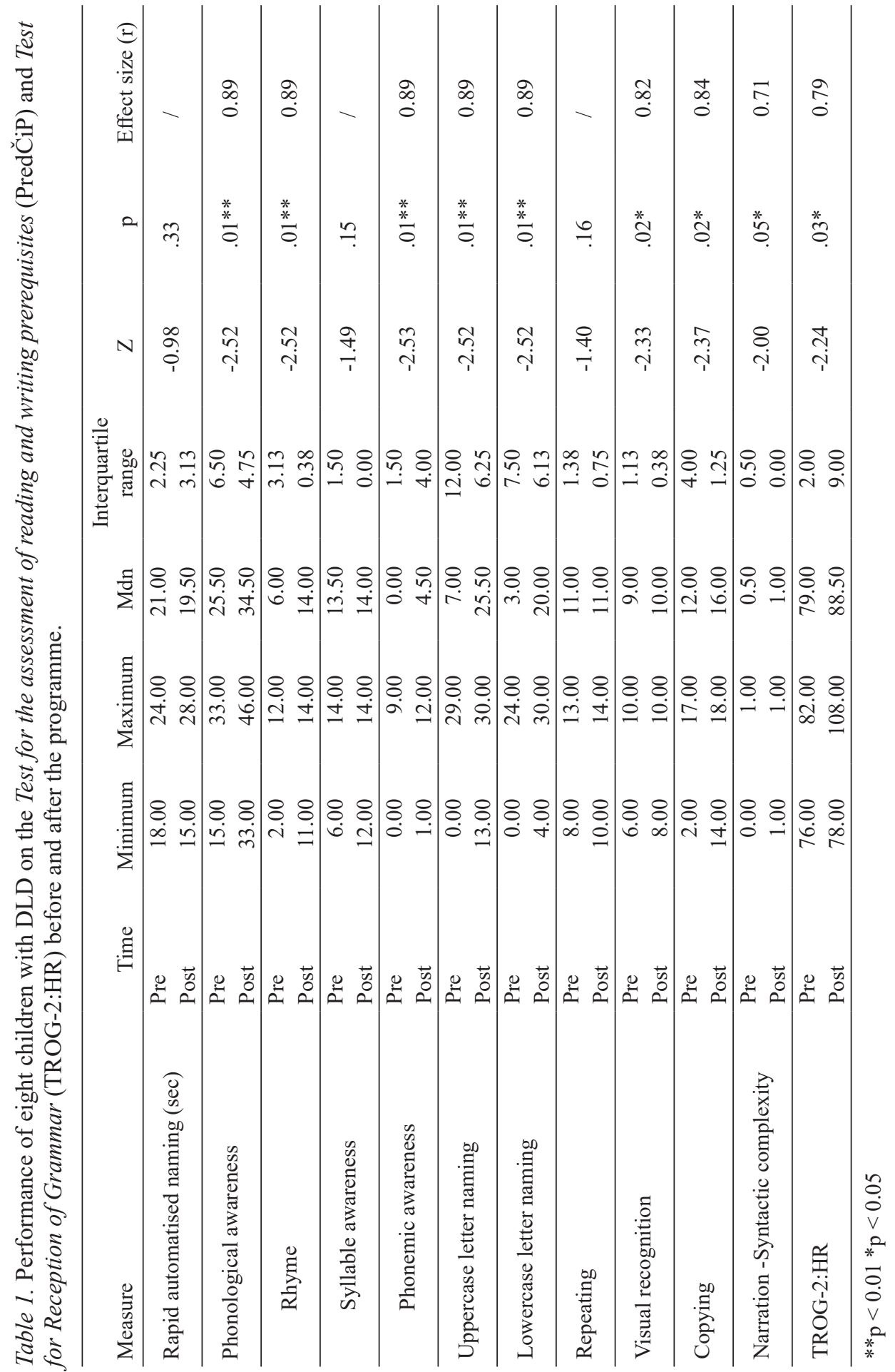


Table 2. Norm groups, standardised growth expectation (SGE) and pre- and post-test z-score difference.

\begin{tabular}{|c|c|c|c|c|c|c|}
\hline \multicolumn{4}{|c|}{ Norm groups (years; months) } & \multicolumn{2}{|c|}{ Z-scores } & \\
\hline$N$ & Pre-test & Post-test & SGE & Pre-test & Post-test & difference \\
\hline 1 & & & & -1.55 & -1.18 & 0.37 \\
\hline 2 & $5 ; 6-5 ; 11$ & $6 ; 0-6 ; 5$ & -0.41 & -1.55 & -1.18 & 0.37 \\
\hline 3 & & & & -1.33 & 0.25 & 1.58 \\
\hline 4 & & & & -1.64 & -0.41 & 1.23 \\
\hline 5 & $6 ; 0-6 ; 5$ & $6 ; 6-6 ; 11$ & -0.49 & -1.18 & -1.08 & 0.10 \\
\hline 6 & & & & -1.50 & 0.55 & 2.05 \\
\hline 7 & $6 \cdot 6-6 \cdot 11$ & $7 \cdot 0-7 \cdot 11$ & 013 & -1.28 & -1.50 & -0.22 \\
\hline 8 & $6 ; 6-6 ; 11$ & $7 ; 0$ - 7;11 & -0.13 & -1.28 & -0.50 & 0.78 \\
\hline
\end{tabular}

Considering the fact that this test places the participants in three age-based norm groups, SGE has been calculated for all three norm groups (Table 2).

The difference between pre- and post-testing cannot over exceed the value of SGE calculated for each age-based norm group. According to this, seven out of eight participants achieved greater scores than the ones expected in terms of maturation (Table 2). Therefore, this progress can be attributed to the language therapy with great confidence.

\section{Insights into parental perception of the group therapy}

Most average scores on the first nine questions of the parental questionnaire were 4-5 (5 indicating the highest level of agreement; Table 3). Going back to the three major areas that the questions covered (see Instruments), such high grades indicate the following: (1) clear understanding of the programme and its aims; (2) satisfaction with the therapy programme regarding its outcomes and their own involvement and (3) low agreement with the statement that group therapies can have the same results as individual ones. The lowest average grade (3) was also found for this question, as well as the greatest dispersion in responses $(\mathrm{Mdn}=3 ; \mathrm{Q}=1)$. In contrast, dispersion was between 0 and 0.50 on all other questions.

Parents' responses to the final four open-ended questions were revealing. The advantages of group therapy that parents indicated most often were an increase in the child's confidence, ability to receive therapy in a friendly environment, socialisation, preparation for a school environment, ability to receive treatment immediately rather than remain on a waiting list, and ability of parents to participate in the therapy. The areas in which children showed the greatest improvement according to their parents were Letter knowledge and Print awareness. Half of the parents also indicated that their children had significantly improved in language reception and expression, as well as in their ability to focus and pay attention. As can be seen 
Table 3. Descriptive statistics of parental responses on the post-programme questionnaire.

\begin{tabular}{|c|c|c|c|c|c|}
\hline & & Interquartile & & & \\
\hline Statements & Mdn & range & Range & Min. & Max. \\
\hline $\begin{array}{l}\text { 1. Prior to the start of the therapy, all its aims and } \\
\text { activities were explained to me }\end{array}$ & 5.00 & 0 & 0 & 5 & 5 \\
\hline $\begin{array}{l}\text { 2. I had the opportunity to participate by observing } \\
\text { all therapy sessions, and to discuss potential } \\
\text { problems with the SLPs }\end{array}$ & 5.00 & 0 & 0 & 5 & 5 \\
\hline $\begin{array}{l}\text { 3. The group provided opportunities for me to learn } \\
\text { skills to facilitate my child's development. }\end{array}$ & 4.00 & 0.50 & 1 & 4 & 5 \\
\hline $\begin{array}{l}\text { 4. I had confidence in the therapy and services that } \\
\text { the group offered. }\end{array}$ & 5.00 & 0 & 1 & 4 & 5 \\
\hline $\begin{array}{l}\text { 5. The programme provided me with a better } \\
\text { understanding of my child's needs and } \\
\text { capabilities. }\end{array}$ & 5.00 & 0.50 & 3 & 2 & 5 \\
\hline 6. My child benefitted from the group sessions. & 5.00 & 0.25 & 2 & 3 & 5 \\
\hline $\begin{array}{l}\text { 7. I was able to implement the suggested activities at } \\
\text { home. }\end{array}$ & 5.00 & 0.50 & 1 & 4 & 5 \\
\hline $\begin{array}{l}\text { 8. I was comfortable and satisfied with the level of } \\
\text { parent participation in the group. }\end{array}$ & 4.00 & 0.50 & 1 & 4 & 5 \\
\hline $\begin{array}{l}\text { 9. I understand the purpose of Parent training } \\
\text { sessions and I find them useful. }\end{array}$ & 5.00 & 0.50 & 2 & 3 & 5 \\
\hline $\begin{array}{l}\text { 10. I think that group therapy sessions have the same } \\
\text { effect as the individual ones }\end{array}$ & 3.00 & 1.00 & 3 & 2 & 5 \\
\hline
\end{tabular}

from the provided answers, parents indeed felt that the therapy influenced their children's lives on a language-specific level (i.e., literacy), as well as on a broader, non-language-specific level (i.e., an increase of self-confidence). In response to the question about suggestions for future therapy programmes, most indicated their desire for the therapy sessions to include more graphomotoric skills, and to be more frequent and intensive.

\section{DISCUSSION}

DLD is a language impairment that has a big effect on the quality of children's academic and social life. There is a merging number of language therapies, and this is the reason why the discussion on identifying the most effective approach is taking on new urgency across Europe. Long waiting lists for diagnosis and therapy of DLD, along with the low ratio of SLPs to inhabitants (1:4500 in Europe and 1:7000 in Croatia (European Commission/EACEA/Eurydice/Eurostat, 2014), add additional importance to the need for adopting more effective strategies. 
This pre-experimental study is one of the first to indicate that the combined approach to therapy; group-based direct and indirect, can significantly improve literacy in children with DLD, strengthening and extending evidence from studies in the UK and North America. Pre- and post-test assessments of the children showed significant improvement in most literacy measures, especially Rhyme, Letter knowledge and Phonemic awareness. This improvement adds additional importance to the previous findings on the significance of phonic approach to therapy for children with DLD (Brooks, 2007; Lonigan, Burgess \& Jason, 2000; Piasta, Purpura $\&$ Wagner, 2010). The current study proves that this also stands for group setting as has previously been reported in a number of systematic reviews and meta-analyses of language therapies (i.e., Cirrin \& Gillam, 2008; Law et al., 2003, 2010, 2012a). This finding is a direct confirmation of the first hypothesis of the study.

The second goal was to gain insights into parental perception of this approach and their overall attitudes (i.e. regarding the ability to engage in the programme or regarding the therapy's influence on their children's lives). They expressed strong trust in the therapy and reported finding it useful for their children, which is in line with the outcomes observed by Johnson et al. (2012) who reported a high level of parental trust and confidence in the provided language therapy. Additionally, the parents in the current study reported that they felt the benefit of their own involvement in the sense that they gained skills and knowledge important for their child's early literacy development. Parents also reported positive influence of group setting on increasing the child's self-confidence, development of interpersonal and social skills and on preparation for the school setting, as was previously mentioned by $\mathrm{Li}$ berman and Michael (1986). Nevertheless, parents still felt that group therapy did not have the exact same effects as individual therapy. This statement is especially interesting considering the fact that the children included in this pre-experimental study never had any previous language therapy, group or individual. This means that the parents' attitude towards group therapy was not experience-based. Therefore, this statement can be attributed to the fact that every parent wants his or her child to receive as much attention as possible, and to the lack of evidence about - and therefore public awareness of - group language therapy in Croatia.

Group-based direct and indirect approaches to language therapy described in this paper are the first ones carried out in the Croatian logopedic environment that deliver empirical evidence on potential effectiveness and validity as an ultimate outcome. The next step is to conduct a comprehensive evidence-based study and, if it indeed proves effective, educate SLPs on how to implement group-based language therapy and combine it with an indirect approach, constantly monitoring parents' involvement.

There are some limitations to this study, which can be circumvented in the future. The programme tested here combines both a group-based direct component, and an indirect component: children received literacy training from SLPs during group sessions, as well as from parents individually at home. Therefore, the results 
do not allow us to isolate the effects of the group-based direct intervention or the indirect one, but one should bear in mind that this was not the primary intention. Future studies may wish to target this specific question and therefore to separate the two components under well-controlled conditions in order to directly demonstrate the relative contributions of each to early literacy improvement. Moreover, the way that the parents implemented what they learned from the SLP in their homes has not been closely monitored. Future studies should examine whether the degree and quality of parent compliance with training affect their feelings of trust, satisfaction and perception of group therapy. Lastly, this study lacked a control group, so future studies should circumvent this limitation by comparing treated and non treated groups (i.e. in randomized controlled trials: RCTs), as well as individual and group therapies focused on fostering early literacy in children with DLD. They should examine group and indirect therapy programmes in larger cohorts, and attempt to identify optimal therapy intensity.

Despite obvious limitations, this study represents the first step in the tendency to conduct comprehensive effectiveness studies in Croatian speech and language pathology environment.

\section{CONCLUSIONS}

The results of the current pre-experimental study largely confirmed the children's progress in early literacy abilities after group-based language therapy. Despite the simplicity of the design, they suggest that the phonic approach, both within the group setting and involving an indirect approach via parental therapy at home, has a positive effect on fostering early literacy in children with DLD. Also, parents' perception of the therapy was positive. These findings justify more controlled and comprehensive effectiveness studies (such as single-subject experimental studies or RCTs) to verify and extend the initial discoveries. This could be a step forward in establishing evidence-based practices in Croatia, which may open the door to wider acceptance of the group and indirect approach to therapy of children with DLD.

Acknowledgments

This work was carried out as part of the project Prerequisites for academic equality: early recognition of language disorders (IPA4.1.2.2.02.01.c02), supported by an Instrument for Pre-Accession Assistance (IPA) grant in Human Resources Development, and within COST Action IS1406: Enhancing children's oral language skills across Europe and beyond: a collaboration focusing on interventions for children with difficulties learning their first language. 
Special thanks to Elin Thordardottir, $\mathrm{PhD}$, from The School of Communication Science and Disorders at McGill College in Montreal, for careful reading of the manuscript, and useful and constructive comments.

\section{Conflict of interest}

The authors report no conflicts of interest. The authors alone are responsible for the content and writing of this paper.

\section{REFERENCES}

American Speech-Language-Hearing Association - ASHA. (2011). ASHA: Speech-Language Pathology Medical Review Guidelines 2011. Retrieved from http: www.asha.org/ uploadedfiles/slp-medical-review-guidelines.pdf

Bishop, D. V., Kuvač Kraljević, J., Hržica, G., Kovačević, M., \& Kologranić Belić, L. (2014). TROG Test for Reception of Grammar (TROG-2:HR). Jastrebarsko: Naklada Slap.

Botting, N., \& Conti-Ramsden, G. (2000). Social and behavioural difficulties in children with language impairment. Child language teaching and therapy, 16(2), 105-120.

Boyle, J. M. (2007). A randomised controlled trial and economic evaluation of direct versus indirect and individual versus group modes of speech and language therapy for children with primary language impairment. Health technology assessment, 11(25), 1-139.

Bray, M., Todd, C., \& Ross, A. (2005). Therapy: Process and Practice. In M. Bray, C. Todd, \& A. Ross (Eds.), Speech and Language: Clinical Process and Practice (pp. 87-126). London: John Wiley and Sons, Ltd.

Brooks, G. (2007). What works for pupils with literacy difficulties? The effectiveness of intervention schemes. Sheffield: Department for Children, Schools and Families.

Campbell, D. T., \& Stanley, J. C. (1963). Experimental and quasi-experimental designs for research. In N. L. Gage (Ed.), Handbook of research on teaching (pp. 1-13). Chicago, IL: Rand McNally.

Cirrin, F. M., \& Gillam, R. B. (2008). Language intervention practices for school-age children with spoken language disorders: a systematic review. Language, Speech, and Hearing Services in Schools, 39(1), 110-137.

Daly, E. J., Chafouleas, S., \& Skinner, C. (2005). Interventions for reading problems. Designing and evaluating effective strategies. New York: Guilford Press.

European Commission/EACEA/Eurydice/Eurostat. (2014). Key Data on Early Childhood Education and Care in Europe, 2014 Edition. Eurydice and Eurostat Report. Luxembourg: Publications Office of the European Union.

Gregl, A., Kirigin, M., Sućeska Ligutić, R., \& Bilać, S. (2014). Emotional competence of mothers and psychopathology in preschool children with specific language impairment (SLI). Psychiatria Danubina, 26(3), 261-270. 
Johnson, N., Moffatt, J., Smith, J., \& White, C. (2012). A Guide to Early Intervention Group Therapy. Maple Ridge: Ridge Meadows Child Development Centre Society.

Kuvač Kraljević, J., \& Lenček, M. (2012). Test for the assessment of reading and writing prerequisites (Pred $\check{C} i P$ ). Jastrebarsko: Naklada Slap.

Kuvač Kraljević, J., Lenček, M., \& Matešić, K. (2019). Phonological awareness and letter knowledge: indicators of early literacy in Croatian. Croatian Journal of Education, 20.

Law, J., Garrett, Z., \& Nye, C. (2003). Speech and language therapy interventions for children with primary speech and language delay or disorder (Review). London: John Wiley and Sons, Ltd.

Law, J., Garrett, Z., \& Nye, C. (2010). Speech and language therapy interventions for children with primary speech and language delay or disorder (Review). Cochrane Database of Systematic Reviews 5. London: John Wiley and Sons, Ltd.

Law, J., Garrett, Z., Nye, C., \& Dennis, J. (2012a). Speech and language therapy interventions for children with primary speech and language delay or disorder (Cochrane Review: update of the 2003 Review). London: John Wiley and Sons, Ltd.

Law, J., Lee, W., Roulstone, S., Wren, Y., Zeng, B., \& Lindsay, G. (2012b). “What works”: Interventions for children and young people with speech, language and communication needs. London: Department for Education.

Law, J., Rush, R., Parsons, S., \& Schoon, I. (2009). Modelling developmental language difficulties from school entry into adulthood: Literacy, mental health and employment outcomes. Journal of Speech, Language, and Hearing Research, 52(6), 1401-1416.

Liberman, D. R., \& Micheal, A. (1986). Group therapy revisited: using cooperative learning procedures in speech language therapy. NSSLHA Journal, 14, 51-67.

Lindsay, G., Dockrell, J., Law, J., \& Roulstone, S. (2012). The Better Communication Research Programme: Improving provision for children and young people with speech, language and communication needs. London: Department for Education.

Lonigan, C. J., \& Shanahan, T. (2011). Executive Summary: Developing Early Literacy. Report of the National Early Literacy Panel. US: National Institute for Literacy and National Centre for Family Literacy.

Lonigan, C. J., Burgess, S. R., \& Jason, A. L. (2000). Development of emergent literacy and early reading skills in preschool children: Evidence from a latent-variable longitudinal study. Developmental psychology, 36(5), 596-613.

Marsden, E., \& Torgerson, C. J. (2012). Single group, pre-and post-test research designs: Some methodological concerns. Oxford Review of Education, 38(5), 583-616.

Matić, A., Kologranić Belić, L., \& Kuvač Kraljević, J. (2015). Grupna jezična terapija. In J. Kuvač Kraljević (Ed.), Priručnik za prepoznavanje i obrazovanje djece s jezičnim teškoćama (pp. 100-112). Zagreb: Faculty of Education and Rehabilitation Sciences.

McCartney, E., Boyle, J., Ellis, S., Bannatyne, S., \& Turnbull, M. (2011). Indirect language therapy for children with persistent language impairment in mainstream primary schools: outcomes from a cohort intervention. International journal of language \& communication disorders, 46, 74-82.

Piasta, S. B., Purpura, D. J., \& Wagner, R. K. (2010). Fostering alphabet knowledge development: A comparison of two instructional approaches. Reading and Writing, 23(6), 607-626. 
Rannard, A., Lyons, C., \& Glenn, S. (2005). Parent concerns and professional responses: the case of specific language impairment. British journal of general practice, 55(518), 710-714.

Raven, J. C. (1995). Coloured Progressive Matrices ${ }^{\mathrm{TM}}$ (CPM $\left.{ }^{\mathrm{TM}}\right)$. Croatian version. Jastrebarsko: Naklada Slap.

Roulstone, S., \& Lindsay, G. (2012). The perspectives of children and young people who have speech, language and communication needs, and their parents. London: Department for Education.

Roulstone, S., Wren, Y., Bakopoulou, I., Goodlad, S., \& Lindsay, G. (2012). Exploring interventions for children and young people with speech, language and communication needs: A study of practice. London: Department for Education.

Russell, M. (2000). Using Expected Growth Size Estimates To Summarize Test Score Changes. Practical Assessment, Research \& Evaluation, 7(6), 1-5.

Schooling, T., Venediktov, R., \& Leech, H. (2010). Evidence-Based Systematic Review: Effects of Service Delivery on the Speech and Language Skills of Children From Birth to 5 Years of Age. Rockville, Mass: ASHA.

Stenner, A. J., Hunter, E. L., Bland, J. D., \& Cooper, M. L. (1978). The standardized growth expectation: Implications for educational evaluation. Retrieved from http: archive.org/ stream/ERIC_ED169072\#page/n5/mode/2up

Tate, R. L., Perdices, M., McDonald, S., Togher, L., \& Rosenkoetter, U. (2014). The design, conduct and report of single-case research: Resources to improve the quality of the neurorehabilitation literature. Neuropsychological Rehabilitation, 24(3), 315-331.

Wake, M., Levickis, P., Tobin, S., Zens, N., Law, J., Gold, L., Ukoumunne, O. C., Goldfeld, S., ND Le, H., Skeat, J., \& Reilly, S. (2012). Improving outcomes of preschool language delay in the community: protocol for the Language for Learning randomised controlled trial. BMC pediatrics, $12(1), 12-96$.

\title{
GRUPNA IZRAVNA I NEIZRAVNA JEZIČNA TERAPIJA ZA DJECU S RAZVOJNIM JEZIČNIM POREMEĆAJEM: PRED-EKSPERIMENTALNI NACRT
}

\begin{abstract}
Sažetak
Razvojni jezični poremećaj (RJP) jedan je od najzastupljenijih poremećaja komunikacije u ranom djetinjstvu sa značajnim utjecajem na djetetov školski uspjeh i društveni život. Tradicionalna logopedska terapija usmjerena prema ovoj populaciji djece počiva na individualnoj terapiji u izravnom radu s logopedom. Noviji terapijski trendovi sve su više usmjereni prema grupnoj terapiji u izravnom radu s logopedom. Također, recentna istraživanju upućuju i na mogućnost uključivanja neizravnog pristupa koji provodi roditelj pod mentorstvom i nadzorom logopeda. Iako je učinkovitost
\end{abstract}


grupne terapije i neizravnog pristupa dokazana širom svijeta, one su još uvijek nedovoljno zastupljene u Hrvatskoj.

Ovaj rad s pred-eksperimentalnim nacrtom predstavlja prvi korak u provedbi empirijski utemeljene studije učinkovitosti. Glavni su ciljevi 1) ispitati mogu li dva pristupa terapiji - izravni u grupi te neizravni u kućnom okruženju - potaknuti razvoj vještina rane pismenosti djece s RJP, te 2) steći uvid u roditeljske stavove o grupnoj terapiji i njezinu utjecaju na živote djece. U programu je sudjelovalo osmero djece i njihovih roditelja. Dječji se jezični napredak mjerio jezičnim testovima prije i nakon provođenja programa, dok su stavovi roditelja ispitani upitnikom po završetku terapije.

Rezultati upućuju na to da grupna terapija, provedena izravno i neizravno, može unaprijediti vještine rane pismenosti djece s RJP-om. Roditelji su izrazili visoko povjerenje u ovakav način provođenja terapije te ga smatraju korisnim za svoje dijete. Ishodi ovog pred-eksperimentalnog istraživanja potvrđuju spoznaje o pozitivnim učincima pažljivo planiranih terapija. Ovo je ujedno prvi korak u provedbi empirijski utemeljene studije učinkovitosti kojoj je cilj početak provedbe logopedskih terapija utemeljenih na znanstvenim i empirijskim dokazima.

Ključne riječi: Razvojni jezični poremećaj, pred-eksperimentalni nacrt, grupna jezična terapija, izravni i neizravni pristup, rana pismenost. 